\title{
Adsorption of Cobalt (II) on Layered Double Hydroxides (Mg/Al and Ca/Al) In Aqueous Medium : Kinetic and Thermodynamic Aspect
}

\author{
Neza Rahayu Palapa ${ }^{1}$, Tarmizi Taher ${ }^{2}$, Muhammad Said ${ }^{1}$, Risfidian Mohadi ${ }^{1}$, Aldes Lesbani ${ }^{1 *}$ \\ ${ }^{1}$ Magister of Chemistry, Faculty of Mathematic and Natural Sciences, Sriwijaya University, Jl.. Padang Selasa Bukit Besar Palembang 30139 \\ ${ }^{2}$ 2Department of Enviromental Science, Graduate School, Sriwijaya University, Jl. Padang Selasa No. 524 Ilir Barat 1, Palembang-South Sumatra, Indonesia \\ *Corresponding author: aldeslesbani@pps.unsri.ac.id
}

\begin{abstract}
Layered double hydroxides $\mathrm{Mg} / \mathrm{Al}$ and $\mathrm{Ca} / \mathrm{Al}$ has been synthesized by co-precipitation method with molar ratio $\mathrm{M}^{2+}: \mathrm{M}^{3+}(3: 1)$ at $\mathrm{pH}$ 10. The synthesized materials were characterized by XRD and FTIR. The materials were used as adsorbent for the removal Cobalt (II) in aqueous solution. The adsorption experiments were studied through some variables adsorption such as variation of contact time, variation of temperature and variation of initial concentration. Kinetic parameters was obtained from variation of contact time. Data was analyzed by pseudo-first-order and pseudo-second-order kinetics models in linear analyses. The kinetic studies showed that the adsorption process more fitted by pseudo-second-order than pseudo-first-order based on coefficient correlation. Isotherm parameters was calculated using Langmuir and Freundlich isotherm models. The adsorption process was spontaneous and endothermic.
\end{abstract}

Keywords

layered double hydroxides, adsorption, Cobalt (II)

Received: 14 September 2018, Accepted: 19 October 2018

https://doi.org/10.26554/sti.2018.3.4.189-194

\section{INTRODUCTION}

Layered material are classified into two groups, cationic clays and anionic clays. Cationic clays are found in nature and anionic clays are easily synthesized. Layered double hydroxides (LDH) belong to the anionic clay minerals was consist of sheets of the hydroxides of two metals different valence. The metals hydroxides layeres are positively charged, so neutrality charged requires must be anion intercalated into interlayer. Usually, hydroxil ions was present as anion and this anion can be readily exchanged by others such as carbonate ions (Rosenberg and Armstrong, 2016).

LDHs has general formula $\left[\mathrm{M}^{2+}(1-\mathrm{x}) \mathrm{M}^{3+} \mathrm{x}(\mathrm{OH})_{2}\right](\mathrm{An}-) \mathrm{x} / \mathrm{nH}_{2}$ where $\mathrm{M}^{2+}$ and $\mathrm{M}^{3+}$ are di-valent and tri-valent cations such as $\mathrm{Mg}^{2+}, \mathrm{Fe}^{2+}, \mathrm{Co}^{2+}, \mathrm{Cu}^{2+}, \mathrm{Ni}^{2+}, \mathrm{Ca}^{2+}$ and $\mathrm{Al}^{3+}, \mathrm{Cr}^{3+}, \mathrm{Ga}^{3+}$, $\mathrm{Mn}^{3+}$ or $\mathrm{Fe}^{3+}$ (Hongo et al., 2017). This layer materials have high flexibility cation exchange and easily synthesized in laboratory (Zhao et al., 2011). Layered double hydroxide has many potential aplications for layered double hydroxides including catalysis, adsorption and flame retardant composite (Clark et al., 2017).

There have been many studies were focusing on the aplication of layered double hydroxides as adsorbent Zhao et al. (2011); El-Sayed et al. (2016); Said and Palapa (2017). Lay- ered double hydroxides was used to adsorpted heavy metals Zhao et al. (2011) and stable at pH >5 up to 12 (Costantino et al., 2013). As known, the presence of heavy metals in the environment can be harmful to variety of living species. Therefor, the removal of heavy metals from waste water is important to public health. The industrial waste water usually containing cobalt (II) is common. The adsorption of heavy metals in solution can be removed using several technique such as adsorption, precipitation, coagulation, chemical precipitation, ion-exchange, ozonation and membran filtration (Shou et al., 2015). The adsorption is recognized as an easy, economic and effective to removed heavy metals from the waste water (El-Sayed et al., 2016; Taher et al., 2018).

In this research, synthesis and characterization of layered double hydroxides was conducted using Frourier Transform Infra Red (FT-IR) and X-Ray Difractometer (XRD). The adsorption process of layered double hydroxides is intended to determine the kinetic and thermodynamic parameters by measuring residual concentration and adsorbed using Atomic Adsorption Spectrophotometer.

\section{EXPERIMENTAL SECTION}

The chemicals used are analytical grade such as magnesium nitrate, alumunium nitrate, calsium nitrate, sodium carbon- 
ate, sodium hydroxide and cobalt nitrate. Water was supplied from Integrated Research Lab Graduated School, Sriwijaya University. Analysis instrument were used FT-IR Shimadzu Prestige-21, XRD Shimadzu Lab X-Type 6000 and Atomic Adsorption Spectrophotometer NovAA 350 Analytic Jena.

\subsection{Synthesis of Layered Double Hydroxides}

Synthesis of layered double hydroxides $\mathrm{Mg} / \mathrm{Al}$ was conducted according to (Palapa and Said, 2016). Synthesis of layered double hydroxides $\mathrm{Ca} / \mathrm{Al}$ was conducting using $100 \mathrm{~mL}$ of a solution containing $0.3 \mathrm{~mol} \mathrm{Ca}\left(\mathrm{NO}_{3}\right)_{2} \cdot \mathrm{H}_{2} \mathrm{O}$ and $0.1 \mathrm{~mol}$ $\mathrm{Al}\left(\mathrm{NO}_{3}\right) \cdot{ }_{9} \mathrm{H}_{2} \mathrm{O}$ under vigorous stirring, while was added dropwise $2 \mathrm{~mol} / \mathrm{L}$ of $\mathrm{NaOH}$ at $\mathrm{pH} 11$ then stirring until $24 \mathrm{~h}$ to form white solid material and dried at room temperature to obtain $\mathrm{Ca} / \mathrm{Al}$ layered double hydroxides (Rojas, 2014).

\subsection{Adsorption Experiment}

Kinetic Parameter $0.05 \mathrm{~g}$ layered double hydroxides $\mathrm{Mg} / \mathrm{Al}$ and $\mathrm{Ca} / \mathrm{Al}$ each added into $50 \mathrm{~mL}$ of cobalt (II) shaker with variations in contact time varied. The solution of the adsorbed cobalt (II) substance was separated by filtration and then measured its concentration by using Atomic Adsorption Spectrophotometer. Thermodynamic Parameter Thermodynamic adsorption of cobalt (II) using adsorbent $0.05 \mathrm{~g}$ layered double hydroxides $\mathrm{Mg} / \mathrm{Al}$ and $\mathrm{Ca} / \mathrm{Al}$ each added into $50 \mathrm{~mL}$ cobalt (II) by variying the with each adsorption temperature is $30{ }^{\circ} \mathrm{C}, 35^{\circ} \mathrm{C}, 40{ }^{\circ} \mathrm{C}, 45{ }^{\circ} \mathrm{C}, 50{ }^{\circ} \mathrm{C}$. The solution of the adsorbed cobalt (II) substance was separated by filtration and then measured its concentration by using Atomic Adsorption Spectrophotometer.

\section{RESULTS AND DISCUSSION}

\subsection{Adsorbent Characterization}

Characterization of layered double hydroxide was carried out using the FT-IR. The FT-IR of the layered double hydroxides $\mathrm{Mg} / \mathrm{Al}$ and $\mathrm{Ca} / \mathrm{Al}$ is shown in Figure 1. The vibration at wavenumber $3300-3800 \mathrm{~cm}^{-1}$ is assigned as streching of $\mathrm{O}-\mathrm{H}$ and the bending of $\mathrm{O}-\mathrm{H}$ at $1635 \mathrm{~cm}^{-1}$. The bending of nitrate is appeared at wavenumber $1381-1388 \mathrm{~cm}^{-1}$. These vibration was unique vibration for layered double hydroxides. The vibrations of $\mathrm{Al}-\mathrm{O}, \mathrm{Ca}-\mathrm{O}$ and $\mathrm{Mg}-\mathrm{O}$ were appreated at $563 \mathrm{~cm}^{-1}, 424 \mathrm{~cm}^{-1}$ and $416 \mathrm{~cm}^{-1}$ respectively.

The XRD patterns of $\mathrm{Mg} / \mathrm{Al}$ and $\mathrm{Ca} / \mathrm{Al}$ material were shown in Figure 2. The unique structure of layered double hydroxides was identified at diffraction angle. This difraction 100 and 600 indicated that presence of layered materials and the anion on the interlayered. XRD pattern of $\mathrm{Ca} / \mathrm{Al}$ in Figure $2 \mathrm{~b}$ was shown semiliar to that reported by Hongo et al. (2017) when synthesis of material was carried out at temperature was $27^{\circ} \mathrm{C}$ (room temperature), the peak intensity of calcite was stong, its because layered double hydroxides contained calcite.

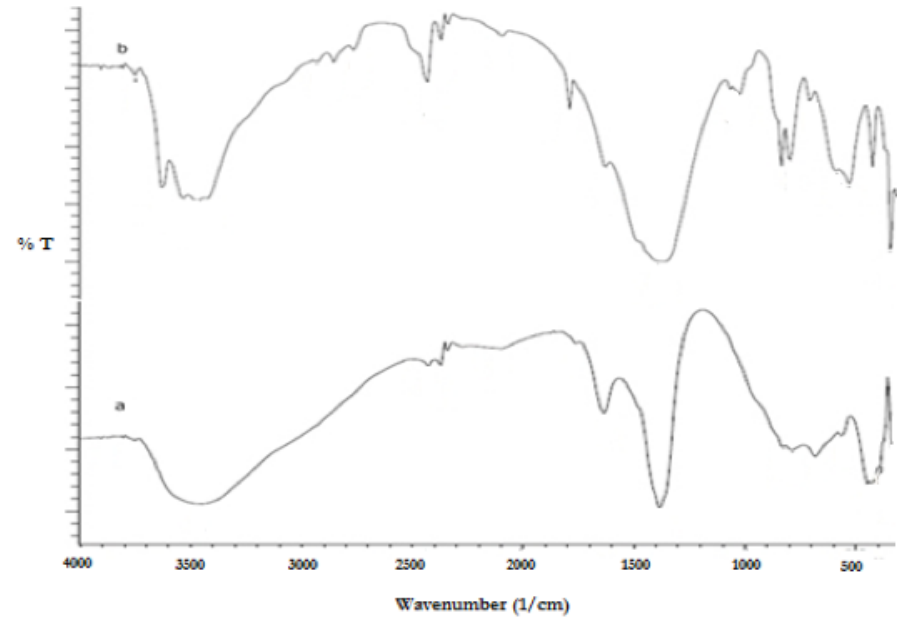

Figure 1. FT-IR spectrum of layered double hydroxides $\mathrm{Mg} / \mathrm{Al}$ (a) and layered double hydroxides $\mathrm{Ca} / \mathrm{Al}(\mathrm{b})$

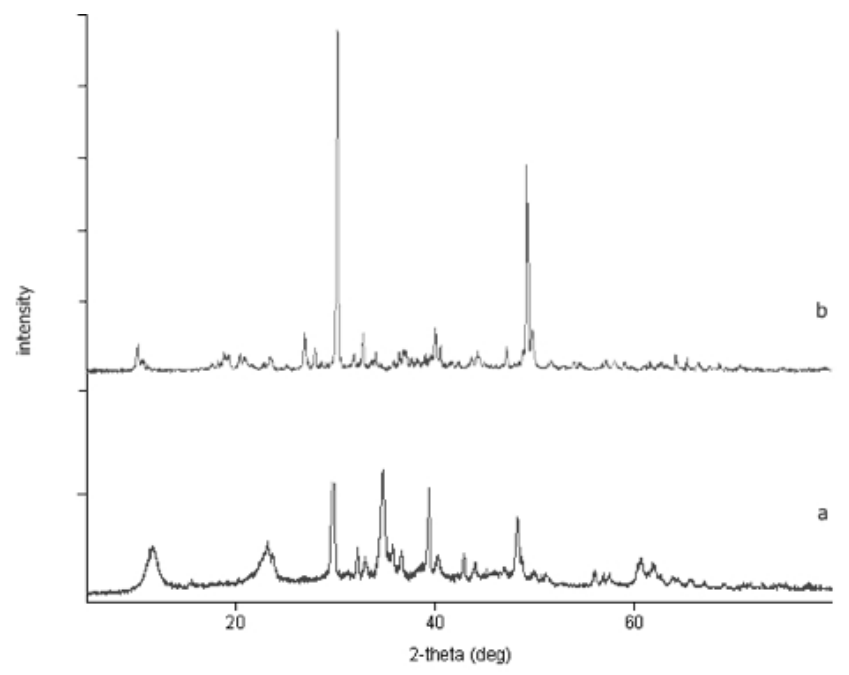

Figure 2. XRD patterns of layered double hydroxides $\mathrm{Mg} / \mathrm{Al}$ (a) and layered double hydroxides $\mathrm{Ca} / \mathrm{Al}$ (b)

\subsection{Kinetic Adsorption of Cobalt (II) on $\mathrm{Mg} / \mathrm{Al}$ and $\mathrm{Ca} / \mathrm{Al}$ Layered Double Hydorxides}

In order to establish the equilibrium time for maximum adsorption, the adsorption of of cobalt (II) was investigated as the function of contact time. Kinetic adsorption of cobalt (II) on layered double hydroxides $\mathrm{Mg} / \mathrm{Al}$ and $\mathrm{Ca} / \mathrm{Al}$ was studied by investigated adsorption time as shown in Figure 3.

Figure 3 shows that $\mathrm{Mg} / \mathrm{Al}$ and $\mathrm{C} / \mathrm{Al}$ layered double hydroxide increased slowly after an hour with percentage adsorp $84 \%$ and $78 \%$, respectively. The fast removal adsorption can happen because the adsorbent surfaces have large number of site to adsorb Co(II) solution, then the rate of adsorbent was decreased when the surface site full of adsorbate accumulated. To identify the rate kinetics of the adsorption process, two kinetics models, namely the pseudo-first-order (PFO) and seudo-second-order (PSO) have been employed to fit the experimental data. The 


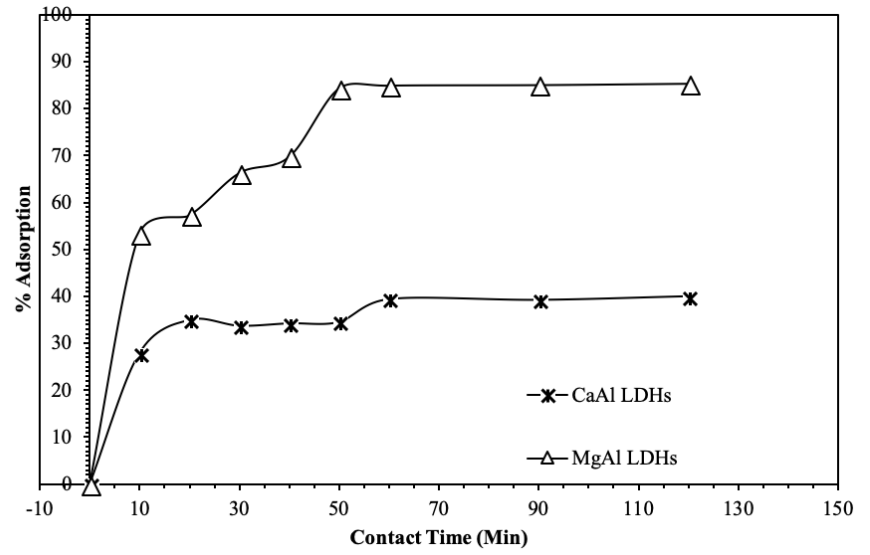

Figure 3. Effect of contact time on the adsorption of Cobalt (II) onto $\mathrm{Mg} / \mathrm{Al}$ and $\mathrm{Ca} / \mathrm{Al} \mathrm{LDH}$

pseudo-first-order kinetics model desribes the adsorption of liquid/solid system based on solid capacity. The model can be written as:

$$
\begin{aligned}
& \frac{d q t}{d t}=k 1(q e-q t) \\
& \log (q e-q t)=\log q e-\frac{k 1}{2.303} t
\end{aligned}
$$

where qe and qt are the capacity of metal ions adsorbed (mg $\mathrm{g}^{-1}$ ) at equilibrium and time $\mathrm{t}(\mathrm{h})$, respectively, and $\mathrm{K} 1$ is the PFO rate constant $\left(\mathrm{h}^{-1}\right)$.

Thus the value of qe and $\mathrm{k} 1$ can be determined experimentally by plotting $\log (\mathrm{qe}-\mathrm{qt})$ versus $\mathrm{t}$ and extracting information from the least squares analysis of slope and intersept into eq (1). The seudo-second-order adsorption kinetic is expressed as following formulation:

$$
\begin{aligned}
& \frac{d q t}{d t}=k 2(q e-q t)^{2} \\
& \frac{t}{q t}=\frac{1}{k 2 q e^{2}}+\frac{1}{q e} t
\end{aligned}
$$

Where $\mathrm{k} 2\left(\mathrm{~g} \mathrm{mg}^{-1} \mathrm{~h}^{-1}\right)$ is the PSO rate constant for the adsorption process. Thus values of $\mathrm{k} 2$ and qe can be calculated from intercept and the slope of the linear relationship eq (4) between $\mathrm{t} / \mathrm{qt}$ and $\mathrm{t}$.

The calculated values of $\mathrm{k} 1, \mathrm{k} 2$, and coefficient correlation $\left(\mathrm{R}^{2}\right)$ obtain in Table 1 . The result indicated that linear of PFO model did not give reasonable values with regard to the experimentals of $\mathrm{Co}(\mathrm{II})$. However, the $\left(\mathrm{R}^{2}\right)$ values are low for linear PFO comparing with $\left(\mathrm{R}^{2}\right)$ values obtain from PSO. These result suggest that the second order mechanism is predominant,
Table 1. Kinetics models for the adsorption of Co (II)

\begin{tabular}{llrr}
\hline \multirow{2}{*}{ kinetics models } & parameters & $\mathrm{Mg} / \mathrm{Al}$ & \multicolumn{1}{c}{$\mathrm{Ca} / \mathrm{Al}$} \\
\hline Pseudo-first-order & qe exp $(\mathrm{mg} / \mathrm{g})$ & 17.0769 & 16.9949 \\
& qe calc $(\mathrm{mg} / \mathrm{g})$ & 18.7013 & 13.2092 \\
& $\mathrm{k} 1(\mathrm{~min}-1)$ & 0.0714 & 0.0359 \\
& $\mathrm{R}^{2}$ & 0.9367 & 0.9722 \\
Pseudo-Seconds-order & qe exp $(\mathrm{mg} / \mathrm{g})$ & 17.0769 & 16.9949 \\
& qe calc $(\mathrm{mg} / \mathrm{g})$ & 18.7798 & 18.3765 \\
& $\mathrm{k} 2(\mathrm{~min}-1)$ & 0.0053 & 0.0185 \\
& $\mathrm{R}^{2}$ & 0.992 & 0.995 \\
\hline
\end{tabular}

in which the adsorption mechanism depends on the adsorbate and adsorbent.

The result was shown in Table 1 . Table 1 was calculated value of $k 1$ and $k 2$, qe exp, qe calc together with $\left(\mathrm{R}^{2}\right)$. The value of correlation coefficient $\mathrm{MgAl}$ and $\mathrm{Ca} / \mathrm{Al}\left(\mathrm{R}^{2}\right)=0.99$ for pseudo-second-order model was better fitted than pseudo-firstorde for adsorption $\mathrm{Co}$ (II) by $\mathrm{MgAl}$ and $\mathrm{Ca} / \mathrm{Al}$ layered double hydroxides, respectively. The data obtained in Table 1 also showed that the layered double hydroxides $\mathrm{Mg} / \mathrm{Al}$ has a more reactive than $\mathrm{Ca} / \mathrm{Al}$ because layered double hydroxides $\mathrm{Mg} / \mathrm{Al}$ has the adsorption rate $\left(0.0053\left(\mathrm{~min}^{-1}\right)\right)$ lower than layered double hydroxides $\mathrm{Ca} / \mathrm{Al}\left(\mathrm{min}^{-1}\right)$.

\subsection{Thermodynamic Adsorption of Cobalt (II) on $\mathrm{Mg} / \mathrm{Al}$ and $\mathrm{Ca} / \mathrm{Al}$ Layered Double Hydroxides}

The Thermodinamics parameters was studied by varied of concentration and temperature. Thermodynamics were used two models isotherm for this data Langmuir and Freundlich ishotherm models. The Langmuir assumed that adsorbate was occupied onto monolayer. Its used equation as follows:

$$
\frac{C e}{q e}=\frac{1}{k L q \max }+\frac{C e}{q \max }
$$

Where qe is the equilibrium adsorption, $\mathrm{Ce}$ is equilibrium concentration, qmax is the maximum adsorption and $\mathrm{kL}$ is the equilibrium adsorption constant. Then, the essential features of Langmuir isotherm namely RL (equilibrium parameters). Value RL has indicated the models of isotherm. If irreversible, the $\mathrm{RL}$ calculated zero $(\mathrm{RL}=0)$, liniear when $\mathrm{RL}=1$, and favorable when $0>$ RL $>1$ (Kumar et al., 2012).

The Freundlich isotherm model identified the heterogenous adsorbent surface. The equation is following:

$$
\log q e=\log k F+n \log C e
$$

Where $\mathrm{kF}$ is adsorption capacity when equilibrium. Thermodynamic adsorption of cobalt (II) on layered double hydroxides $\mathrm{Mg} / \mathrm{Al}$ and $\mathrm{Ca} / \mathrm{Al}$ was studied by variying concentration and temperature. Adsorption data by layered double hydroxides $\mathrm{Mg} / \mathrm{Al}$ and $\mathrm{Ca} / \mathrm{Al}$ in Figure 4 and Figure 5. Therefore, both the isotherm models are shown in Table 2. Based on correlation 
Table 2. Langmuir and Freundlich Isotherm Models

\begin{tabular}{ccccccccc}
\hline $\begin{array}{l}\text { Correlation } \\
\text { Parameter }\end{array}$ & \multicolumn{2}{c}{$\mathrm{T}=303 \mathrm{~K}$} & \multicolumn{2}{c}{$\mathrm{T}=308 \mathrm{~K}$} & $\mathrm{~T}=313 \mathrm{~K}$ & $\mathrm{~T}=318 \mathrm{~K}$ \\
\hline Langmuir & $\mathrm{Mg} / \mathrm{Al}$ & $\mathrm{Ca} / \mathrm{Al}$ & $\mathrm{Mg} / \mathrm{Al}$ & $\mathrm{Ca} / \mathrm{Al}$ & $\mathrm{Mg} / \mathrm{Al}$ & $\mathrm{Ca} / \mathrm{Al}$ & $\mathrm{Mg} / \mathrm{Al}$ & $\mathrm{Ca} / \mathrm{Al}$ \\
Qmax & 18.288 & 17.453 & 22.726 & 18.463 & 25.773 & 21.098 & 36.855 & 21.318 \\
$\mathrm{KL}$ & 0.0626 & 0.071 & 0.085 & 0.077 & 0.080 & 0.070 & 0.0557 & 0.073 \\
$\mathrm{RL}$ & $0.00068-$ & $0.00071-$ & $0.00054-$ & $0.00067-$ & $0.00048-$ & $0.00059-$ & $0.00033-$ & $0.00058-$ \\
& 0.0054 & 0.0056 & 0.0043 & 0.0054 & 0.0035 & 0.0047 & 0.0027 & 0.00046 \\
$\mathrm{R}^{2}$ & 0.996 & 0.994 & 0.995 & 0.994 & 0.995 & 0.992 & 0.994 & 0.991 \\
Freundlich & $\mathrm{Mg} / \mathrm{Al}$ & $\mathrm{Ca} / \mathrm{Al}$ & $\mathrm{Mg} / \mathrm{Al}$ & $\mathrm{Ca} / \mathrm{Al}$ & $\mathrm{Mg} / \mathrm{Al}$ & $\mathrm{Ca} / \mathrm{Al}$ & $\mathrm{Mg} / \mathrm{Al}$ & $\mathrm{Ca} / \mathrm{Al}$ \\
$\mathrm{Kf}$ & 1.391 & 1.933 & 2.025 & 2.040 & 1.969 & 1.847 & 2.1433 & 2.149 \\
$\mathrm{n}$ & 1.505 & 1.802 & 1.476 & 1.856 & 1.366 & 1.537 & 1.299 & 1.609 \\
$\mathrm{R}^{2}$ & 0.894 & 0.706 & 0.741 & 0.718 & 0.798 & 0.677 & 0.848 & 0.829 \\
\hline
\end{tabular}

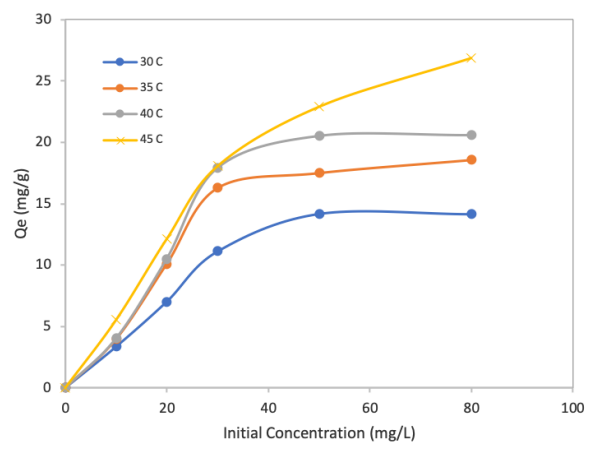

Figure 4. Adsorption of cobalt (II) varied concentration and temperature by layered double hydroxides $\mathrm{Mg} / \mathrm{Al}$

coefficient of the data, Langmuir isotherm models more fitted than Freundlich isotherm models. Its indicated the adsorption was accour in monolayer adsorption coverage onto LDHs particles and also the homogeneous distribution of active sites adsorbent (Lin et al., 2014). the isotherm was found to be linear studied by good correlation coefficient $\left(\mathrm{R}^{2}=0.99\right)$. The data in Table 2 was showed the monolayer adsorption capacity Cobalt (II) have a higher value at $318 \mathrm{~K}$ using $\mathrm{Mg} / \mathrm{Al} \mathrm{LDHs}$ $(36.855 \mathrm{mg} / \mathrm{g})$.

Thermodynamic investigation plays an indispensable part in the prediction of adsorption mechanisms (i.e., physical or chemical). thermodynamic parameters $\left(\Delta \mathrm{G}^{\circ}, \Delta \mathrm{H}^{\circ}\right.$, and $\left.\Delta \mathrm{S}^{\circ}\right)$ can be calculated according to the thermodynamic laws through the following equations:

$$
\Delta G=-R T \ln K c
$$

then, the relationship between thermodynamics parameter written by:

$$
\Delta G=\Delta H-T \Delta S
$$

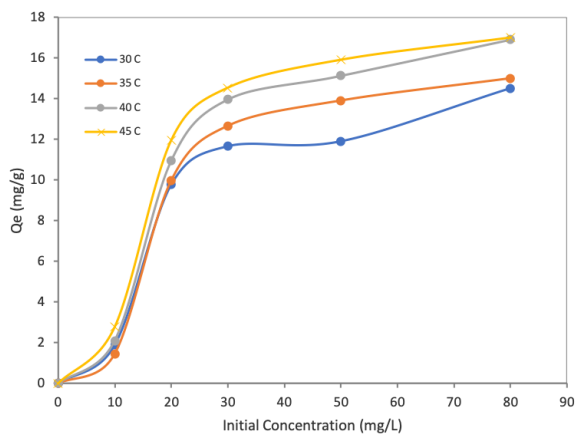

Figure 5. Adsorption of cobalt (II) varied concentration and temperature by layered double hydroxides $\mathrm{Ca} / \mathrm{Al}$

The Van't Hoff equation was obtain by Equation (7) and (8):

$$
\ln K c=\frac{\Delta H}{R} \cdot \frac{1}{T}+\frac{\Delta S}{R}
$$

The Gibbs energy was calculated by Equation (7), then the enthalpy $(\Delta \mathrm{H})$ and the entropy $(\Delta \mathrm{S})$ were obtained from a plot of lnKc versus $1 / \mathrm{T}$, the plot were determined slope and intercept (Equation (9)). In this study the Kc derived from the Langmuir constant (KL) was employed for calculation of the thermodynamic parameters.

The thermodynamic parameters for adsorbing Cobalt (II) onto the $\mathrm{Mg} / \mathrm{Al}$ and $\mathrm{Ca} / \mathrm{Al} \mathrm{LDHs}$ respectively were showed in Table 3 . Table 3 were showed the negative values of $\Delta \mathrm{G}$ were investigated the adsorption was spontaneously. Meanwhile, the positive $\Delta \mathrm{H}$ reflects the endothermic nature of the adsorption process and the equilibrium constant (Table 3) at a higher temperature. Additionally, the positive $\Delta \mathrm{S}$ values suggest that an increase in irregularity on the surface with several structural changes both adsorbate and adsorbent. In addition, when the adsorbate is adsorbed on the surface sites, the adsorbate replaces several molecules of water which is its can increasing the entropy. 
Table 3. Values of Thermodynamic Parameters for The Adsorption of Cobalt (II) By Mg/Al and Ca/Al LDHs

\begin{tabular}{|c|c|c|c|c|c|c|c|}
\hline \multirow[b]{2}{*}{$\mathrm{T}(\mathrm{K})$} & \multirow[b]{2}{*}{ Concentration $(\mathrm{mg} / \mathrm{L})$} & \multicolumn{3}{|c|}{$\mathrm{Mg} / \mathrm{Al}$} & \multicolumn{3}{|c|}{$\mathrm{Ca} / \mathrm{Al}$} \\
\hline & & $\begin{array}{c}\Delta \mathrm{G} \\
(\mathrm{kJ} / \mathrm{mol})\end{array}$ & $\begin{array}{r}\Delta \mathrm{S} \\
(\mathrm{J} / \mathrm{mol} . \mathrm{K})\end{array}$ & $\begin{array}{c}\Delta \mathrm{H} \\
(\mathrm{kJ} / \mathrm{mol})\end{array}$ & $\begin{array}{c}\Delta \mathrm{G} \\
(\mathrm{kJ} / \mathrm{mol})\end{array}$ & $\begin{array}{r}\Delta \mathrm{S} \\
(\mathrm{J} / \mathrm{mol} . \mathrm{K})\end{array}$ & $\begin{array}{c}\Delta \mathrm{H} \\
(\mathrm{kJ} / \mathrm{mol})\end{array}$ \\
\hline 303 & & -4.712 & & & -1.005 & & \\
\hline 308 & & -6.429 & & & -2.384 & & \\
\hline 313 & 10 & -8.145 & 85.806 & 21.286 & -3.736 & 69.614 & 21.666 \\
\hline 318 & & -8.784 & & & -3.943 & & \\
\hline 303 & & -2.762 & & & -0.199 & & \\
\hline 308 & 90 & -5.049 & 111936 & 37480 & -1.104 & 84961 & 33365 \\
\hline 313 & 20 & -7.336 & 111.200 & 01.400 & -2.008 & 84.201 & 00.000 \\
\hline 318 & & -8.309 & & & -3.489 & & \\
\hline 303 & & -1.381 & & & -0.245 & & \\
\hline 308 & 30 & -4.823 & 114240 & 91809 & -1.175 & 06004 & 49864 \\
\hline 313 & 00 & -8.265 & 114.042 & 01.000 & -2.105 & 90.094 & 42.004 \\
\hline 318 & & -8.905 & & & -4.997 & & \\
\hline 303 & & -0.231 & & & -0.378 & & \\
\hline 308 & 50 & -0.463 & 138846 & 44383 & -0.984 & 110654 & 58.418 \\
\hline 313 & 00 & -3.248 & 100.040 & 44.000 & -1.591 & 110.004 & 00.410 \\
\hline 318 & & -4.567 & & & -3.856 & & \\
\hline 303 & & -0.672 & & & -0.378 & & \\
\hline 308 & & -2.114 & & & -0.984 & & \\
\hline 313 & 80 & -3.082 & 172.093 & 50.761 & -1.591 & 122.035 & 78.148 \\
\hline 318 & & -3.787 & & & -2.345 & & \\
\hline
\end{tabular}

\section{CONCLUSIONS}

Adsorption process of cobalt (II) on layered double hydroxides $\mathrm{Mg} / \mathrm{Al}$ and $\mathrm{Ca} / \mathrm{Al}$ showed the adsorption rate $0.0053 \mathrm{~min}^{-1}$ and $0.0185 \mathrm{~min}^{-1}$, respectively. Layered double hydroxides $\mathrm{Mg} / \mathrm{Al}$ more reactive than layered double hydroxides $\mathrm{Ca} / \mathrm{Al}$. The adsorption kinetics investigation revealed that the adsorption of both dyes was followed the pseudo-second-order kinetics model. Isotherm parameters was calculated using Langmuir and Freundlich isotherm models. Based on adsorption data, Langmuir isotherm models more fitted than Freundlich, its indicated the adsorption was accour in monolayer adsorption coverage onto LDHs particles. The adsorption process was spontaneous and endothermic

\section{REFERENCES}

Clark, I., P. W. Dunne, R. L. Gomes, and E. Lester (2017). Continous Hydrothermal Synthesis of Ca2Al-NO3 Layered Double Hydroxides: The impact of Reactor Temperature, Pressure and $\mathrm{NaOH}$ Concentration on Crystal Characteristics. Journal of Colloid and Interface Science, 504; 492-499

Costantino, U., F. Leroux, M. Nocchetti, and C. Mousty (2013). LDH in Physical, Chemical, Biochemical, and Life Sciences. In Developments in Clay Science. Elsevier, pages 765-791

El-Sayed, M., G. Eshaq, and A. E. ElMetwally (2016). Adsorption of Heavy Metals from Aqueos Solution by $\mathrm{Mg}-\mathrm{Al}-\mathrm{Zn}$ Mingled Oxides Adsorbent. Water Science and Technology, 74(7); 1644-1657
Hongo, T., Y. Tsunashima, and A. Yamasaki (2017). Synthesis of Ca-Al layered double hydroxide from concrete sludge and evaluation of its chromate removal ability. Sustainable Materials and Technologies, 12; 23-26

Kumar, P. S., C. Senthamarai, and A. Durgadevi (2012). Adsorption kinetics, mechanism, isotherm, and thermodynamic analysis of copper ions onto the surface modified agricultural waste. Environmental Progress \& Sustainable Energy, 33(1); 28-37

Lin, Y., Q. Fang, and B. Chen (2014). Metal composition of layered double hydroxides (LDHs) regulating $\mathrm{ClO}-4$ adsorption to calcined LDHs via the memory effect and hydrogen bonding. Journal of Environmental Sciences, 26(3); 493-501

Palapa, N. R. and M. Said (2016). Keggin Type Polyoxometalate As Intercalated Hydrotalcite. Science and Technology Indonesia, 1(1); 25-28

Rojas, R. (2014). Copper, lead and cadmium removal by Ca $\mathrm{Al}$ layered double hydroxides. Applied Clay Science, 87; 254259

Rosenberg, S. P. and L. Armstrong (2016). Layered Double Hydroxides in the Bayer Process: Past, Present and Future. In Essential Readings in Light Metals. Springer International Publishing, pages 235-239

Said, M. and N. R. Palapa (2017). Adsorption of congo red using $\mathrm{Mg} / \mathrm{Al}$ hydrotalcite. Science and Technology Indonesia, 1(2); 17-21

Shou, J., C. Jiang, F. Wang, M. Qiu, and Q. Xu (2015). Fab- 
rication of Fe3O4/MgAl-layered Double Hydroxides Magnetic Comosites for The Effective Decontamination of Co(II) from Synthetic Wastewater. Journal of Molecular Liquids, 207; 216-223

Taher, T., D. Rohendi, R. Mohadi, and A. Lesbani (2018). Thermal and Acid Activation (TAA) of Bentonite as Adsorbent for Removal of Methylene Blue: A Kinetics and
Thermodynamic Study. Chiang Mai Journal of Science., 45; 1770-1781

Zhao, D., G. Sheng, J. Hu, C. Chen, and X. Wang (2011). The adsorption of $\mathrm{Pb}$ (II) on $\mathrm{Mg} 2 \mathrm{Al}$ layered double hydroxide. Chemical Engineering Journal, 171(1); 167-174 